\title{
COMPARISON OF RECURRENCE INCIDENCE AFTER PTERYGIUM EXCISION BY USING PEROPRATIVE SUBCONJUNCTIVAL BEVACIZUMAB INJECTION VERSUS CONJUNCTIVAL AUTO GRAFT
}

By

\section{Mohamed El-Sayed Mohamed Abd El-Wahab, Hisham Fawzy Khalel and Abd Al-Magid Mohamed Tag Al-Din}

Ophthalmology Department, Faculty of Medicine, Al-Azhar University Cairo, Egypt

Corresponding author: Mohamed El-Sayed Mohamed Abd El-Wahab

Mobile: 01005373241, E-mail: $\underline{\text { m.deghesh@yahoo.com }}$

\begin{abstract}
Background: A pterygium is a fleshy, wing-shaped growth from the conjunctiva, crossing over the limbus onto the cornea. The tissue is fibrovascular and can occur over the nasal or temporal cornea. It can be a bilateral process and asymmetric with one eye affected by a larger pterygium than the other.
\end{abstract}

Objectives: To compare between Subconjunctival injection of bevacizumab (Avastin) and conjunctival autograft in the treatment of primary pterygium.

Patients and Methods: This study was performed on 40eyes of 40 patients with primary pterygia of variable durations. The eyes were randomly classified into two equal groups: group A patients to be treated by Subconjunctival Bevacizumab (avastin) $0.2 \mathrm{ml}(5 \mathrm{mg}$ ) for Primary Pterygium Excision, group B patients treated by conjunctival auto graft. Best corrected visual acuity, occurrence of recurrence, IOP and postoperative complications were compared. Patients were evaluated preoperatively then 1 day, 1 week, 1 month, 3 months after surgery. Eye photography was done before surgery and during the follow up period. This study was conducted at Department of Ophthalmology Al-Azhar University Hospital and Kobry El Kobba Military Hospital, from August 2018 to July 2020.

Results: When the two groups were compared together, we found no statistically significant differences among them in multiple compared items, but the recurrence rate in group A (bevacizumab group) occurred in $(10 \%)$, while in group B conjunctival auto graft no recurrence occurred and this was statistically insignificant difference among the 2 groups. There were no statistically significant differences regarding improvement in visual acuity, intraocular pressure change and postoperative complications among the two groups.

Conclusion: A single preoperative subconjunctival injection of bevacizumab had decreased the recurrence rate befor primary pterygium excision, but did not give a more desirable recurrence rate. On the other hand conjunctival autograft was more effective than bevacizumab in reducing the recurrence rate of primary pterygium after surgical excision.

Keywords: Recurrence Incidence, Pterygium Excision, Peroprative Subconjunctival Bevacizumab Injection, Conjunctival Auto Graft. 


\section{INTRODUCTION}

Pterygium is a common worldwide eye disease affecting population especially in tropical and subtropical areas. It is a degenerative fibrovascular proliferation of conjunctival tissue over the cornea (from the Greek, pterygos, "little wing").The tissue is fibrovascular and can occur over the nasal (usually) or temporal cornea (uncommon). It can be a bilateral process and asymmetric with eye affected by a larger pterygium than the other. In addition two pterygia can affect a single eye, one nasally and the other temporally. The pterygium consists of collagen tissue that is hyperplastic and denatured, marked by elastic degeneration (degeneration of collagen fibers) (Clearfield et al., 2016).

It often is preceded by a growth of the conjunctiva without extension onto the cornea, known as a pingueculum. It is believed that ultraviolet light is a major contributor in the formation of pterygia, though the finding that a high prevalence of pterygium exists outside inhabitants of equatorial regions strongly suggests that reflected, scattered light is also critical.

Both individual susceptibility and environmental exposure appear to be risk factors responsible for the occurrence of pterygium. Incidence and prevalence; affecting population rates range wos from $0.7 \%$ to $31 \%$. Pterygium is twice as common in men as in women It is more prevalent in older age groups, but the incidence is higher in younger individuals. It is uncommon in people younger than 20 years of age and among people who wear glasses. The incidence increases greatly in people between 20 and 40 years of age (Kuo et al., 2014).
Pterygia can impair vision through altered tear film, induced astigmatism, photophobia, epiphora, and binocular diplopia due to contraction of the Tenon's capsule, which limits eye movements. Pterygia can cause symptoms such as eye irritation, foreign body sensation, and dryness. In mild climates, it is unusual for a pterygium to grow over the visual axis, but patients are often concerned about the cosmetic appearance of their eye. In potentially susceptible individuals, the pterygium can grow across the entire corneal surface, impairing vision (Clearfield et al., 2016).

For mild cases of pterygium, conservative topical treatment with lubricants or steroids is recommended. For advanced symptomatic pterygium, several surgical techniques have been developed over the past few decades (Huang et al., 2018).

Although many surgical approaches have been developed, recurrent pterygium represents a significant surgical problem. Reported rates of recurrence range from $2 \%$ to $39 \%$ for excision with conjunctival autograft to $89 \%$ for bare scleral excision. Differences in study morphology, patient characteristics, nature of pterygium, geographic area, definition of recurrence, duration of follow-up, and loss of followup are some of the factors responsible for widely varying rates of recurrence (Sun et al., 2011).

Surgical treatment options for pterygium include the following:

1. Bare sclera excision (Chui et al., 2011). 
2. Bare sclera excision with postoperative beta irradiation (Said et al., 2013).

3. Bare sclera excision with perioperative mitomycin $\mathrm{C}$ application (Kinast et al., 2016).

4. Pterygium excision with conjunctival autograft (free) or rotational flape (Huang et al., 2018).

5. Pterygium excision with conjunctival limbal autograft (Genidy et al., 2017).

6. Pterygium excision with amniotic membrane graft (Hussain et al., 2020).

Despite evolutional and modification of pterygium excision techniques, recurrence continues to be a limiting factor for success (Hovanesian et al. 2017).

The challenge continues to find an adjunctive agent with long-term safety and efficacy (Razeghinejad et al., 2010).

In recurrent pterygium, angiogenesis plays a key role in the formation of fibrovascular tissue. In recent years, angiogenesis inhibitors have gained popularity for the management of various neovascular and proliferative ocular diseases. VEGF is one of the key elements in angiogenesis. It exerts its effect binding to vascular endothelial growth factor (VEGF) receptors (VEGF receptor 1 and VEGF receptor 2), which are expressed on vascular endothelial cells. VEGF blockage can lead to inhibition of formation of new vessels. Anti-VEGF may also produce antifibrotic effect (Ahmed et al, 2019).

Bevacizumab (Avastin) a recombinant, humanized antiVEGF monoclonal antibody (Rosenfeld et al., 2016).
The present work aimed to compare the recurrence rate of the pterygium in the patients treated by Pterygium excision with auto conjunctival graft and the patients treated by Subconjunctival Bevacizumab (avastin) a week preoperative.

\section{PATIENTS AND METHODS}

This was a prospective comparative observation study from August 2018 to July 2020.

It included 40 eyes of 40 patients with Primary pterygium of both sexes and of different age groups.

Written informed consent was obtained from every participant or a legally responsible person after approval by the Institutional Ethic Committee.

Patients were divided into two equal groups: Group A was treated by Subconjunctival Bevacizumab (avastin) $0.2 \mathrm{ml}(5 \mathrm{mg})(100 \mathrm{mg} / 4 \mathrm{ml}$ Roche) for Primary Pterygium Excision; Group B was treated by conjunctival autograft for Primary Pterygium Excision.

Study site: Al- Azhar University Hospital and Kobry El-Kobba Military Hospital.

\section{Inclusion criteria:}

- Age 30 years or older.

- Sex both.

- Type of pterygium: Primary.

\section{Exclusion criteria:}

- Recurrent pterygium.

- Ocular infection.

- Dry eye syndrome or wound healing problems as ocular cicatricial pemphigoid, immunocompromised patients. 
Preoperative evaluated as follow:

\section{History taking:}

\section{Personal History:}

-Age, sex, occupation, and residence and immunosuppressive complaints.

-Visual symptoms, diminution of vision, diplopia.

-Irritation, lacrimation, and photophobia.

-Bad cosmetic appearance.

\section{Present history:}

- Onset, Course (stationary, regressive, slowly progressive), duration of the complaint.

- Any accompanying general disease

- Measurement IOP.

\section{Past history:}

- Similar condition and history of previous ocular operation.

\section{Family history:}

- Of any similar conditions

\section{Surgical technique:}

\section{Injection technique:}

All injections were performed under microscopy at $10 \mathrm{x}$ magnification, after placing topical of Benoxinate HCL $0.4 \%$ in the eye, a self-retaining lid retractor was placed and the patient was asked to direct the eye to be injected in extreme horizontal gaze to have adequate exposure of the pterygium, using a $1 \mathrm{ml}$ syringe with 30-gauge needle, $5 \mathrm{mg}(0.2 \mathrm{ml})$ of bevacizumab was injected in the subconjunctival area of the body of the pterygium. Two drops of moxifloxacin hydrochloride were subsequently instilled in the eye. The lid retractor was removed and the patient was sent home for one week.

\section{Operative Technique:}

Both groups were under surgical excision.

\section{Steps:}

1. Sterilization.

2. Anesthesi.

3. Lid speculum is applied.

4. Saline injection under pterygium to facilitate its dissection.

5. Avulsion technique was used for removal as follow.

\section{Postoperative treatment:}

Topical combination of corticosteroid and antibiotic eye drops were used and pad was supplied for 24 hours. Antibiotic and steroid were used 4 times a day for a month and the tapered during this period.

\section{Postoperative examination:}

- Uncorrected distance visual acuity (UDVA).

- Corrected distance visual acuity (CDVA).

- Full ophthalmic evaluation with slitlamp examination, IOP and recording of any complication.

- The main outcome measures were the recurrence rate.

- The postoperative complications. Sutures were removed at 3rd week.

- Follow up to 3 months. 


\section{Statistical Analysis:}

Data were collected, revised, coded and entered to the Statistical Package for Social Sciences (IBM SPSS) version 23. The quantitative data were presented as mean, standard deviations and ranges when their distribution found parametric. Qualitative variables were presented as number and percentages. So, the p-value was considered significant when $\mathrm{P}<0.05$.
The comparison between the studied groups regarding qualitative data was done by using Chi-square test.. The comparison between two independent groups with quantitative data and parametric distribution were done by using Independent t-test while two groups with paired data were compared by using Paired t-test.

\section{RESULTS}

There were 16 patients (80\%) 30 to 50 years, 4 patients $(20 \%) 50$ - 60 years in group A (p-value $=0.465)$ while there were 14 patient $(70 \%) 30$ - 50 years, 6 patients (30\%) $50-60$ years in group B $(\mathrm{p}$-value $=0.158)$. There were 18 males $(90 \%)$ and 2 females (10\%) in group A while there were 18 males $(90 \%)$ and 2 females $(10 \%)$ in group B (p-value =
1.00).There were 17 patients $(85 \%)$ working outdoor and 3 patients (15\%) working indoor in group A while there were 15 patients $(75 \%)$ working outdoor and 5 patients $(25 \%)$ working indoor in group B (p-value $=0.625)$. No statistical significant difference ( $\mathrm{p}$-value $>0.05$ ) between studied groups as regard main complaints (Table 1).

Table (1): Comparison between studied groups as regard demographic data Description the main complaints in the studied patients was variable

\begin{tabular}{|c|c|c|c|c|c|c|}
\hline \multicolumn{2}{|c|}{$\begin{array}{ll}\text { Parameters } & \text { Groups } \\
\end{array}$} & \multicolumn{2}{|c|}{ Group A } & \multicolumn{2}{|c|}{ Group B } & P-value \\
\hline \multicolumn{2}{|c|}{ Demographic data } & \multicolumn{2}{|c|}{ No. $=20$} & \multicolumn{2}{|c|}{ No. $=20$} & \\
\hline \multirow{4}{*}{ Age } & $30-50$ & \multicolumn{2}{|c|}{$16(80.0 \%)$} & \multicolumn{2}{|c|}{$14(70.0 \%)$} & \multirow{2}{*}{0.465} \\
\hline & $>50$ & \multicolumn{2}{|c|}{$4(20.0 \%)$} & \multicolumn{2}{|c|}{$6(30.0 \%)$} & \\
\hline & Mean \pm SD & \multicolumn{2}{|c|}{$45.45 \pm 5.21$} & \multicolumn{2}{|c|}{$48.15 \pm 6.56$} & \multirow{2}{*}{0.158} \\
\hline & Range & \multicolumn{2}{|c|}{$37-56$} & \multicolumn{2}{|c|}{$36-60$} & \\
\hline \multirow{2}{*}{ Sex } & Female & \multicolumn{2}{|c|}{$2(10.0 \%)$} & \multicolumn{2}{|c|}{$2(10.0 \%)$} & \multirow{2}{*}{1.000} \\
\hline & Male & \multicolumn{2}{|c|}{$18(90.0 \%)$} & \multicolumn{2}{|c|}{$18(90.0 \%)$} & \\
\hline \multirow{2}{*}{ Occupation } & Outdoor & \multirow{2}{*}{\multicolumn{2}{|c|}{$\frac{17(85.0 \%)}{3(15.0 \%)}$}} & \multirow{2}{*}{\multicolumn{2}{|c|}{$\frac{15(75.0 \%)}{5(25.0 \%)}$}} & 0470 \\
\hline & Indoor & & & & & 0.429 \\
\hline \multicolumn{2}{|c|}{ Main complaints } & No. & $\%$ & No. & $\%$ & \\
\hline \multicolumn{2}{|c|}{ Ocular irritation } & 6 & $30.0 \%$ & 6 & $30.0 \%$ & 1.000 \\
\hline \multicolumn{2}{|c|}{ Irritation and cosmetic comp } & 10 & $50.0 \%$ & 8 & $40.0 \%$ & 0.525 \\
\hline \multicolumn{2}{|c|}{ Cosmetic comp } & 2 & $10.0 \%$ & 4 & $20.0 \%$ & 0.375 \\
\hline \multicolumn{2}{|c|}{$\begin{array}{l}\text { Irritation and visual } \\
\text { disturbance }\end{array}$} & 2 & $10.0 \%$ & 2 & $10.0 \%$ & 1.000 \\
\hline
\end{tabular}


No statistical significant difference between studied groups as regard pre and post-operative best corrected VA, and as regard post-operative best corrected VA after 1 and 3 months (Table 2).

Table (2): Description of pre and post-operative best corrected visual acuity in both groups and visual acuity changes after 1 and 3 months

\begin{tabular}{|c|c|c|c|c|c|}
\hline $\begin{array}{ll}\text { Parameters } & \text { Groups } \\
\end{array}$ & \multicolumn{2}{|c|}{ Group A } & \multicolumn{2}{|c|}{ Group B } & \multirow{2}{*}{ P-value } \\
\hline Pre-operative best corrected VA & No. & $\%$ & No. & $\%$ & \\
\hline $6 / 6$ & 10 & $50.0 \%$ & 12 & $60.0 \%$ & 0.525 \\
\hline $6 / 9$ & 2 & $10.0 \%$ & 2 & $10.0 \%$ & 1.000 \\
\hline $6 / 12$ & 4 & $20.0 \%$ & 2 & $10.0 \%$ & 0.376 \\
\hline $6 / 18$ & 4 & $20.0 \%$ & 4 & $20.0 \%$ & 1.000 \\
\hline \multicolumn{6}{|l|}{$\begin{array}{c}\text { Post-operative best corrected VA } \\
\text { (after } 1 \text { month) }\end{array}$} \\
\hline $6 / 6$ & 10 & $50.0 \%$ & 12 & $60.0 \%$ & 0.525 \\
\hline $6 / 9$ & 2 & $10.0 \%$ & 6 & $30.0 \%$ & 0.114 \\
\hline $6 / 12$ & 6 & $30.0 \%$ & 2 & $10.0 \%$ & 0.114 \\
\hline $6 / 18$ & 2 & $10.0 \%$ & 0 & $0.0 \%$ & 0.147 \\
\hline \multicolumn{6}{|l|}{ Visual acuity change (after 1 month) } \\
\hline Improved & 2 & $10.0 \%$ & 4 & $20.0 \%$ & \multirow{3}{*}{0.376} \\
\hline Deteriorated & 0 & $0.0 \%$ & 0 & $0.0 \%$ & \\
\hline No change & 18 & $90.0 \%$ & 16 & $80.0 \%$ & \\
\hline \multicolumn{6}{|l|}{$\begin{array}{c}\text { Post-operative best corrected VA } \\
\text { (after } 3 \text { months) }\end{array}$} \\
\hline $6 / 6$ & 10 & $50.0 \%$ & 12 & $60.0 \%$ & 0.525 \\
\hline $6 / 9$ & 2 & $10.0 \%$ & 6 & $30.0 \%$ & 0.114 \\
\hline $6 / 12$ & 6 & $30.0 \%$ & 2 & $10.0 \%$ & 0.114 \\
\hline $6 / 18$ & 2 & $10.0 \%$ & 0 & $0.0 \%$ & 0.147 \\
\hline
\end{tabular}

There was a statistically nonsignificant difference between studied groups as regard recurrence. In group A, recurrence occurred in 2 cases $(10 \%)$. while in group B it occurred in 0 case after 3 months This table shows description of demographic data of patients with recurrence. As regard age, the mean age of patients with recurrence was $40.00 \pm 4.24$ years with minimum age of 37years and maximum age of 43 years. As regard sex, 2 patients $(100 \%)$ were males and 0 patient $(0.00 \%)$ was female. As regard occupation, 2 patients $(100 \%)$ were working outdoor and 0 patients $(0.00 \%)$ were working indoor (Table 3). 
Table (3): Comparison between studied groups as regard recurrence

\begin{tabular}{|c|c|c|c|c|}
\hline \multirow{2}{*}{\multicolumn{2}{|c|}{$\begin{array}{ll}\text { Parameters } & \text { Groups } \\
\end{array}$}} & \multirow{2}{*}{$\begin{array}{c}\text { Group A } \\
\text { No. }=20\end{array}$} & Group B & \multirow{2}{*}{ P- value } \\
\hline & & & No. $=20$ & \\
\hline \multirow{2}{*}{$\begin{array}{l}\text { Recurrence after } 3 \\
\text { months }\end{array}$} & No & 18( & $20(100.0 \%)$ & \multirow{2}{*}{0.147} \\
\hline & Yes & $2(1$ & $0(0.0 \%)$ & \\
\hline \multirow{2}{*}{\multicolumn{3}{|c|}{ Demographic data }} & \multirow{2}{*}{\multicolumn{2}{|c|}{$\begin{array}{c}\text { Recurrence after } 3 \text { months } \\
\text { No. }=2\end{array}$}} \\
\hline & & & & \\
\hline \multirow{2}{*}{\multicolumn{2}{|c|}{ Age }} & Mean \pm SD & \multicolumn{2}{|c|}{$40.00 \pm 4.24$} \\
\hline & & Range & \multicolumn{2}{|l|}{$37-43$} \\
\hline \multirow{2}{*}{\multicolumn{2}{|c|}{ Sex }} & Female & \multicolumn{2}{|l|}{$0(0.0 \%)$} \\
\hline & & Male & \multicolumn{2}{|c|}{$2(100.0 \%)$} \\
\hline \multirow{2}{*}{ Occupation } & \multicolumn{2}{|r|}{ Outdoor } & \multicolumn{2}{|c|}{$2(100.0 \%)$} \\
\hline & & Indoor & \multicolumn{2}{|c|}{$0(0.0 \%)$} \\
\hline
\end{tabular}

There was no statistical significant difference between studied groups as regard pre-operative and post-operative IOP. In group $\mathrm{A}$ the mean preoperative IOP was $14.2 \pm 0.63$, while the mean post- operative IOP was $13.6 \pm 0.96$. In group $\mathrm{B}$, the mean preoperative IOP was $14.1 \pm$ 0.73 , while the mean post-operative IOP was $13.8 \pm 0.63$ (Table 4 ).

Table (4): Comparison between studied groups as regard preoperative intra-ocular pressure

\begin{tabular}{|c|c|c|c|c|}
\hline \multicolumn{2}{|c|}{ Parameters $\quad$ Groups } & Group A & Group B & P-value \\
\hline \multicolumn{2}{|c|}{ Pre-operative IOP } & No. $=20$ & No. $=20$ & \\
\hline \multicolumn{2}{|c|}{$13 \mathrm{mmHg}$} & $2(10.0 \%)$ & $4(20.0 \%)$ & \multirow{3}{*}{0.654} \\
\hline \multicolumn{2}{|c|}{$14 \mathrm{mmHg}$} & $12(60.0 \%)$ & $10(50.0 \%)$ & \\
\hline \multicolumn{2}{|c|}{$15 \mathrm{mmHg}$} & $6(30.0 \%)$ & $6(30.0 \%)$ & \\
\hline \multicolumn{2}{|c|}{ Mean \pm SD } & $14.20 \pm 0.62$ & $14.10 \pm 0.72$ & \multirow{2}{*}{0.639} \\
\hline \multicolumn{2}{|c|}{ Range } & $13-15$ & $13-15$ & \\
\hline \multicolumn{2}{|c|}{ Intra-ocular pressure } & No. $=20$ & No. $=20$ & \\
\hline \multirow{2}{*}{$\begin{array}{l}\text { Pre-operative } \\
\text { IOP }\end{array}$} & Mean \pm SD & $14.20 \pm 0.62$ & $14.10 \pm 0.72$ & \\
\hline & Range & $13-15$ & $13-15$ & \\
\hline \multirow{2}{*}{$\begin{array}{l}\text { Post-operative } \\
\text { IOP }\end{array}$} & Mean \pm SD & $13.60 \pm 0.94$ & $13.85 \pm 0.67$ & \\
\hline & Range & $12-15$ & $13-15$ & \\
\hline \multicolumn{2}{|c|}{ P-value } & 0.001 & 0.021 & \\
\hline
\end{tabular}

There was a case of right Pterygium before conjunctival auto graft in Figure 1A, post-operative conjunctival auto graft with sutures Figure 1- B), after 3 months no recurrence occurred with conjunctival auto graft (Figure 1- C). A case of left Pterygium treated by bevacizumab injection ( Figure 2- A and after 3 months recurrence occurred with bevacizumab injection (Figure (2- B). A Case of postoperative subconjunctival hemorrhage complication with bevacizumab injection Figure 3). 


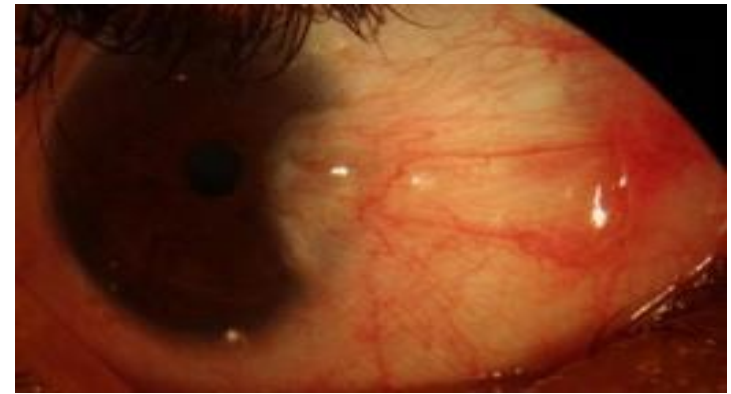

Figure (1-A): Pterygium before. conjunctival autograft

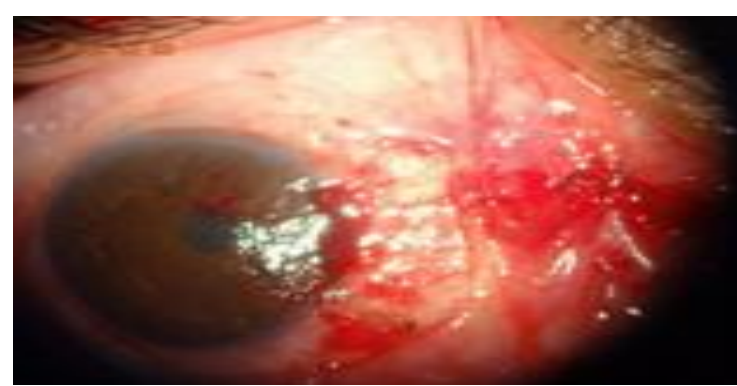

Figure (1-B): Pterygium post conjunctival autograft

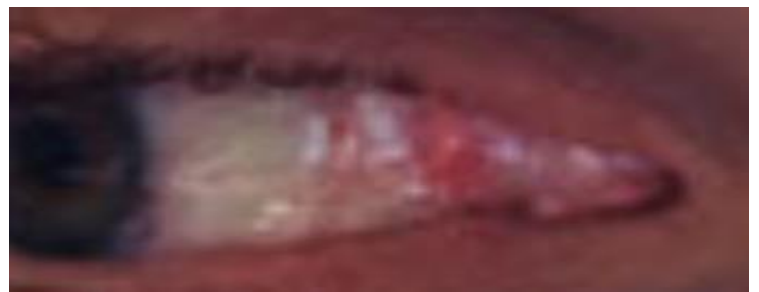

Figure (1-C): No recurrence case with conjunctival autograft autograft after 3 months

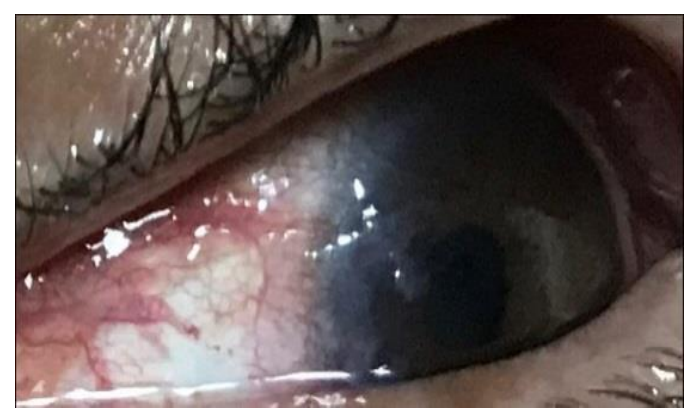

Figure (2-A) :Pterygium before bevacizumab injection

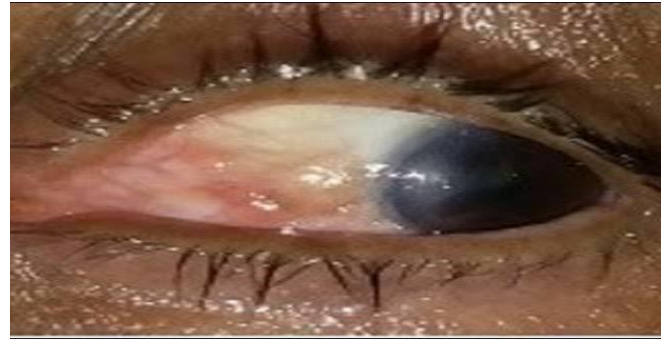

Figure (2-B): Postoperative with recurrence case with bevacizumab injection after 3months

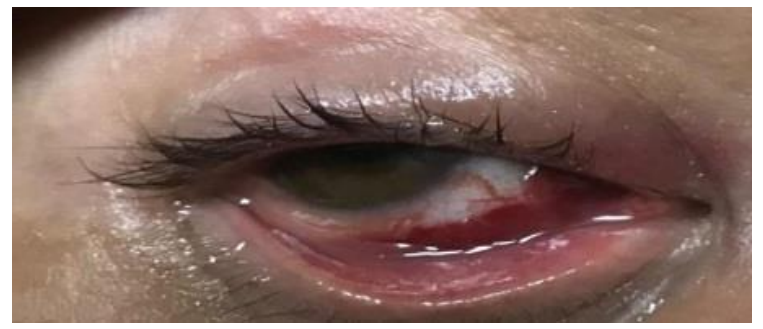

Figure (3):Case of postoperative subconjunctival hemorrhage complication

\section{DISCUSSION}

Regarding the age of the patients of our present study, it ranged from 30-60 years. The higher incidence was found to be in the age group of $30-50$ years $75 \%$. This may be due to maximum exposure to sun light and various irritants in this age, as pterygium is one of the sun related condition. This finding was in agreement with that was recorded by some previous studies Bunga and Kotipalli, (2016) observed that the incidence of pterygium is higher in 3rd and 4th decades. The incidence is lower in 5th decade which 
was $10 \%$, and the highest incidence $65.5 \%$ in the age group $40-49$ years.

Regarding the sex of the patients of our present study, it was found that primary pterygia were common in males $(90 \%)$ than females $(10 \%)$ and the recurrence was more in males $(100 \%)$. These results were parallel to that of Bunga and Kotipall (2016) found that $70 \%$ of the affected patients were males, and 30\% were females. Also, Shenasi et al. (2011) stated that males were $81.8 \%$, and females were $18.2 \%$ in the study group.

Regarding the occupation in our study, pterygia $100 \%$ were working outdoors. Bunga and Kotipalli (2016), found that $76 \%$ of the affected patients were in outdoor group, who are more exposed to sunny and dusty climate, while $24 \%$ were indoor group.

Regarding the site of pterygium, in our study, all patients presented with nasal pterygium which was explained by the role of sun light. These findings were parallel to that of Bunga and Kotipalli (2016) found that 96.4 presented with nasal pterygia, and $3.6 \%$ presented with temporal pterygia.

Regarding the recurrence rate, in our study, the pterygium recurred in 5\%. The recurrence in bevacizumab group occurred in $10 \%$ out of cases. In conjunctival autograft no recurrence occurred. Recurrence was considered when a fibrovascular growth had occurred in the position of the previously excised pterygium, Kocabora et al. (2013) stated that recurrence occurred in $66.7 \%$ of cases of bevacizumab group.

Rashid et al. (2012) found that subconjunctival bevacizumab injection was useful in management of patients with primary pterygium with local or systemic adverse effects. There was a significant difference in the mean surface area of pterygium and the size of pterygium was reduced. Han et al. (2016) studied the clinical effect of subconjunctival administration of bevacizumab in patient primary and recurrent pterygium. They received subconjunctival bevacizumab $(0.02 \mathrm{cc})$. Pterygium vascularity and thickness were graded. The size of the pterygium (measured by surface area in $\mathrm{cm}^{2}$ ) was recorded from baseline to 12 weeks after injection. Treatments related complications and adverse events were reported. The main outcome of measurements was a decrease in size, vascularity, thickness and color intensity, so sub-conjunctival bevacizumab injection is useful in management of patients with primary and recurrent pterygium without significant local or systemic adverse effects.

Razeghineja et al. (2010) evaluated the efficacy of subconjunctival bevacizumab as an adjunctive therapy for primary pterygium surgery. After pterygium exicision and accomplishing a rotational conjunctival flap, patients received $1.25 \mathrm{ml}$ bevacizumab. The recurrence rate was $13.4 \%$ during the follow up period of 8 months, so a single intraoperative injection had no effect on pterygium recurrent rate.

Dos Santos Martins et al. (2016) studied patients with primary and recurrent pterygium who were treated by excision and conjunctival auto-graft. At the end of follow up period (6-12months), the recurrence rate was found to be $5.7 \%$. 
Regarding postoperative complications, in our study, this was 2.5 $\%$ that showed postoperative complications. Complications observed in the bevacizumab group included 5\% that developed subconjunctival hemorrhage. This case improved within 2 weeks.

Mak et al. (2017) found that the most commonly detected complication with bevacizumab was subconjunctival hemorrhage which was self-limited and may be related to the subconjunctival injection only.

Mak et al. (2017) concluded that antiVEGF is safe and no systemic complications were detected. There were no complications observed in conjunctival auto graft regarding the visual acuity. Improvement occurred in 30\%. This improvement may be due to reduced astigmatism and relieved pterygial interruption of visual axis by its surgical removal, irrespective to the adjunctive treatment used.

Regarding intraocular pressure (IOP) changes in the present study, the mean preoperative IOP was $14.20 \pm 0.62$, while the mean postoperative IOP was $13.60 \pm$ 0.94 in bevacizumab group, and the mean preoperative IOP was $14.10 \pm 0.72$ while the mean post-operative IOP was $13.85 \pm$ 0.67 in conjunctival autograft groups. But these changes were statistically insignificance.

\section{CONCLUSION}

Patients treated by conjunctival auto graft were the best method with low recurrence rate and high safety, but has longer duration, and associated with patient discomfort.

\section{REFERENCES}

1. Ahmed M, Ahmed AM and Mirza GK (2019): Role of Topical Cyclosporine in Prevention of Pterygium Recurrence, after Primary Excision. Pakistan Journal of Ophthalmology, 35(3):188-192

2. Bunga $T$ and Kotipalli $L$ (2016): Mitomycin C, Recurrence, Surgical Management, 5-Fluorouracil, Pterygium. A study of management of pterygium: a comparative study, 3(67): 3617-3621.

3. Chui J, Coroneo MT, Tat LT, Crouch R, Wakefield $D$ and Di Girolamo $\mathbf{N}$ (2011): Ophthalmic pterygium: a stem cell disorder with premalignant features. The American Journal of Pathology; 178(2):817-27.

4. Clearfield E, Muthappan V, Wang $X$ and Kuo IC (2016): Conjunctival autograft for pterygium. Cochrane Database of Systematic Reviews;2, Issue .Feb. 2016 Art. No.: CD 011349.

5. Dos Santos Martins TG, de Azevedo Costa AL, Alves MR, Chammas $R$ and Schor P (2016): Mitomycin C in pterygium treatment. International Journal of Ophthalmology, 9(3):465-468.

6. Genidy MM, Abdelghany AA and Alio JL (2017): Tailored corneo-conjunctival autografting in primary and secondary pterygium surgery. European Journal of Ophthalmology, 27(4):407-10.

7. Han SB, Jeon HS, Kim M, Lee SJ, Yang HK, Hwang JM, Kim KG, Hyon JY, and Wee WR (2016): Quantification of astigmatism induced by pterygium using automated image analysis. Cornea, 35(3):370-6.

8. Hovanesian JA, Starr CE, Vroman DT, Mah FS, Gomes JA, Farid M, Shamie N, Davidson RS, John T, Holland EJ and Kim T (2017): Surgical techniques and adjuvants for the management of primary and recurrent pterygia. Journal of 
Cataract and Refractive Surgery, 43(3):405-19.

9. Huang $X$, Zhu B, Lin $L$ and Jin $X$ (2018): Clinical results for combination of fibrin glue and nasal margin suture fixation for attaching conjunctival autografts after pterygium excision in Chinese pterygium patients. Medicine, 97(44): Issue .Nov.2018 Art. No.:13050.

10. Hussain SA, Shaheen KH, Ullah MS and Furqan A (2020): Recurrence of Pterygium after Pterygium Excision with Stem Cell Graft and Amniotic Membrane Graft: A Comparison. Cureus Journal, 12(1): Art. No.: 6535.

11. Kinast RM, Akula KK, DeBarber AE, Barker GT, Gardiner SK, Whitson E and Mansberger SL (2016): The degradation of mitomycin $C$ under various storage methods. Journal of Glaucoma, 25(6):477-81.

12. Kocabora SM, Fazil K, Ozsutcu M, Doyduk-Kocabora A and Gulkilik G (2013): Subconjunctival bevacizumab injection in the surgery of primary pterygium: comparison with intraoperative mitomycin-C. Bull Soc. Belge. Ophthalmol, 322: 7-12.

13. Kuo IC, Muthappan $V$ and Wang $X$ (2014): Conjunctival autograft for pterygium. Cochrane Database of Systematic Reviews, Issue 10. Art. No: CD011349.

14. Mak RK, Chan TCY, Marcet MM, Choy BNK, Shum JWH, Shih KC and Ng ALK (2017): Use of anti- vascular endothelial growth factor in the management of pterygium. Acta Ophthalmologicam 95(1): 20-27.

15. Rashid O, Rimsha S, Waseem R, Arshad R, Shahzada BS and Assif SI
(2012): Role of subconjunctival bevacizumab in treatment of pterygium. Pakistan Journal of Ophthalmology, 28(3): $132-135$.

16. Razeghinejad MR, Hosseini H, Ahmadi F, Rahat $F$ and Eghbal $H$ (2010): Preliminary Results of Subconjunctival Bevacizumab in Primary Pterygium Excision. Ophthalmic Res, 43(3): 134138.

17. Rosenfeld PJ, Fung A, Andrew $M$ and Michels S (2016): Optical coherence tomography and the development of antiangiogenic therapies in neovascular age-related macular degeneration. Investigative Ophthalmology and Visual Science, 57(9):OCT14-26.

18. Said DG, Faraj LA, Elalfy MS, Yeung A, Miri A, Fares U, Otri AM, Rahman I, Maharajan S and Dua HS (2013): Intra-lesional 5 fluorouracil for the management of recurrent pterygium. Eye, 27(10):1123-9.

19. Shenasi A, Mousavi F, Shoa-Ahari S, Rahimi-Ardabili B, and Fouladi RF (2011): Subconjunctival bevacizumab immediately after excision of primary pterygium: the first clinical trial. Cornea, 30(11): 1219-1222.

20. Sun YC, Hsiao CH, Chen WL and Hu FR (2011): Overexpression of matrix metalloproteinase-1 (MMP-1) and MMP3 in superior limbic keratoconjunctivitis. Investigative Ophthalmology and Visual Science, 52(6):3701-5. 


\section{در اســة مقارنـة لمعدلات إرتـجـاع الظـفرة بـعد إز التهـا

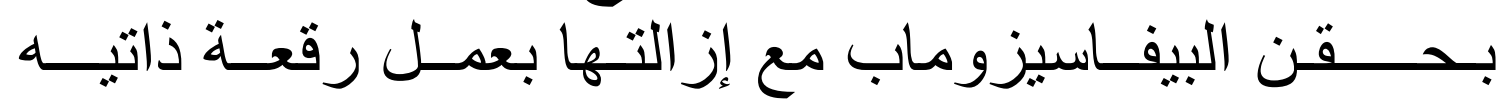

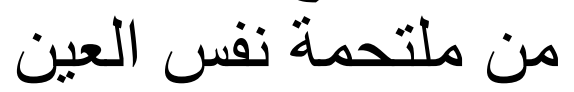

محمد السيد محمد عبد الوهاب، هشام فوزى خليل، عبد المجيد محمد تاج الدين قسم طب وجراحة العيون، كلية الطب، جامعة الازهر، القاهرة، مصر

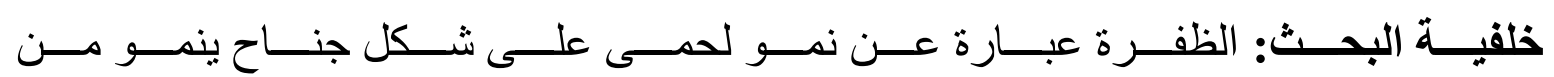

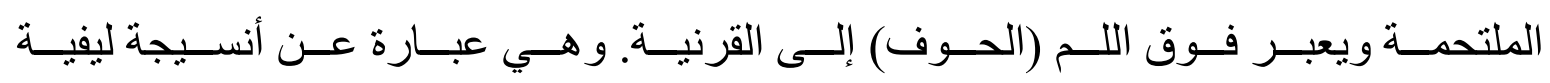

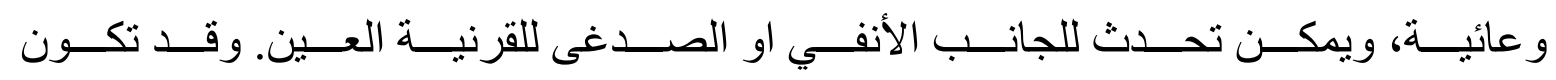

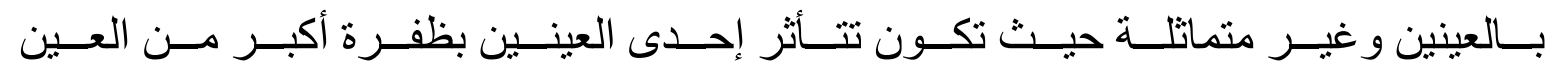

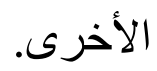

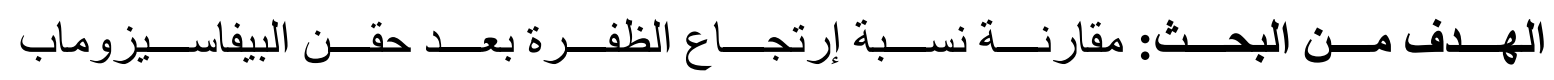

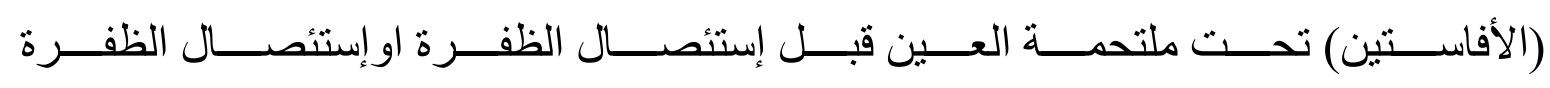
و عمل رقعة ذاتية من الملتحمة من نفس العين.

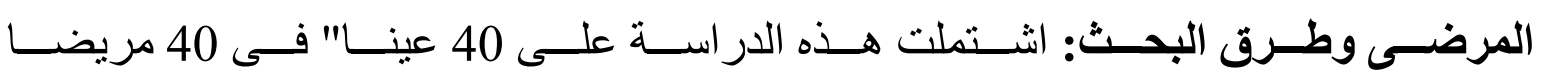

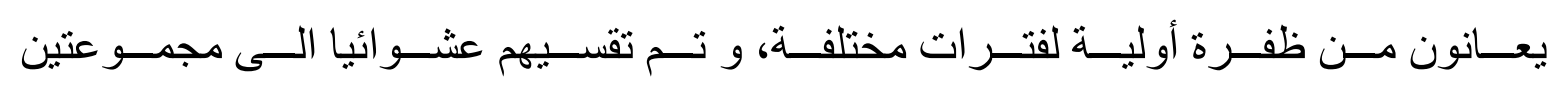

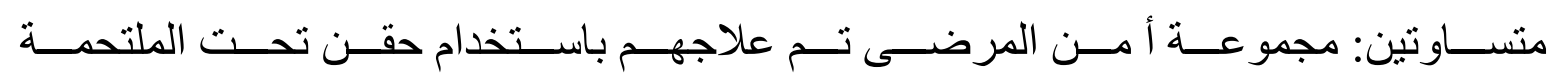

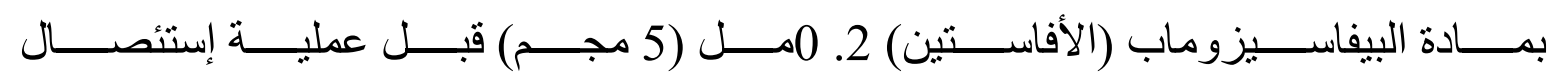

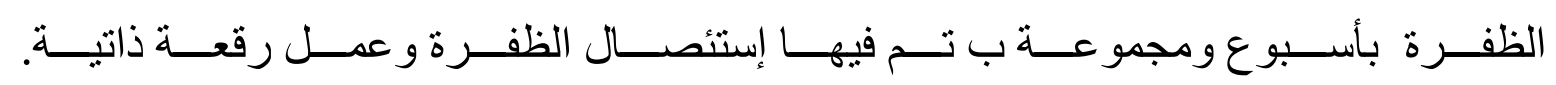

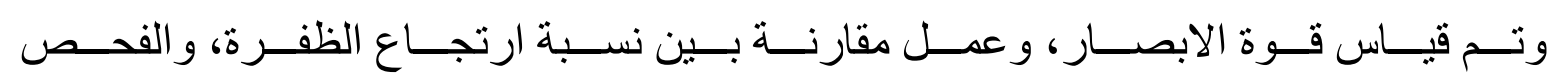

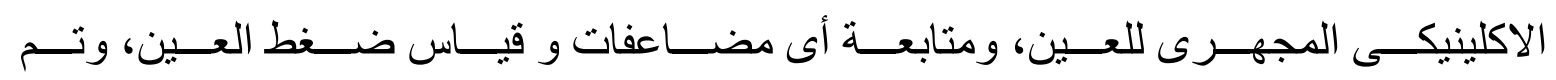

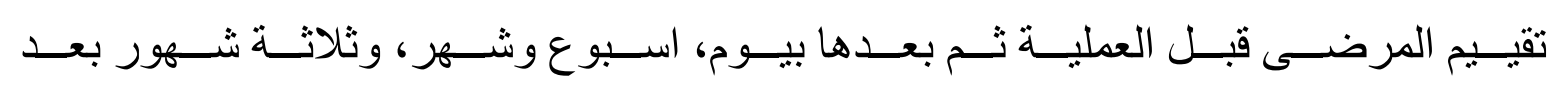

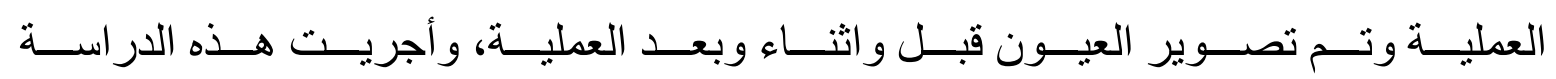

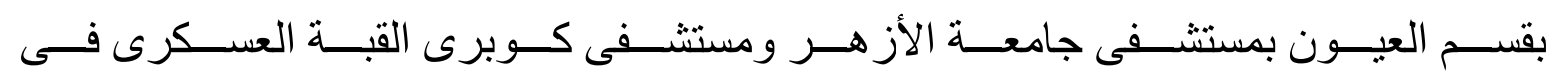
الفترة من أغسطس 2018 الى يوليو 2020. 


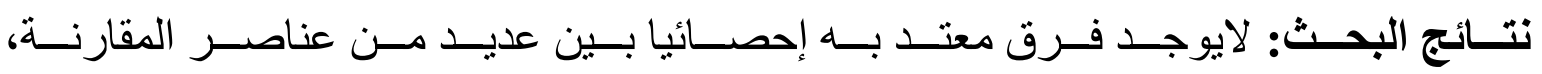
ولكـن كــان معــدل الإرتجـــاع للظفــرة فــى المجوعــة أ (حقـن البيفاســيزوماب) 10

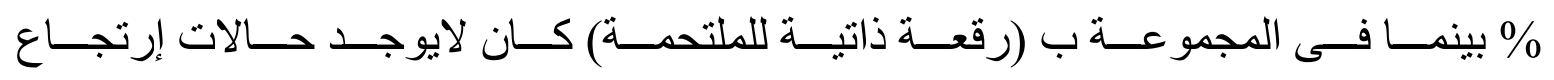

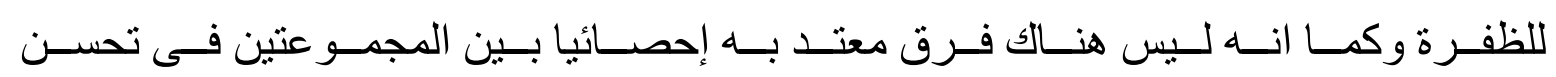
قوة الابصار و التغير فى ضغط العين و المضاعافات بين المجمو عتين.

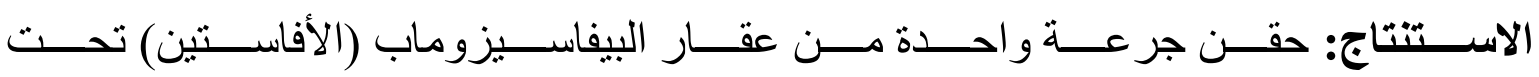

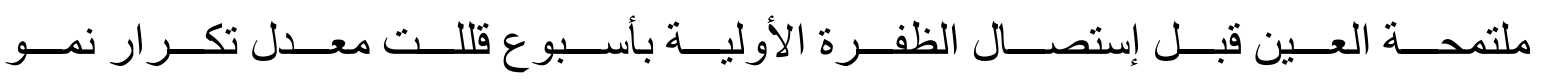

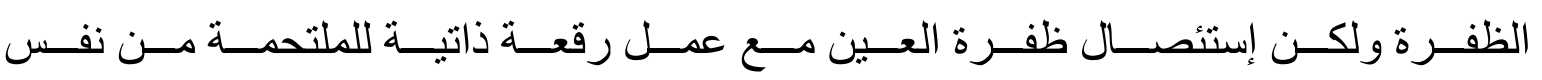
العين هى الافضل نسبيا لمنع تكرار نمو الظفرة. 